\title{
Effect of pre-treatments on the germination and early seedlings growth of Acacia auriculiformis Cunn. Ex. Benth
}

\author{
Olatunji D.*, Maku J. O. and Odumefun O. P. \\ Department of Plant Science and Biotechnology, Adekunle Ajasin University, Akungba-Akoko, Nigeria.
}

Accepted 21 June, 2012

\begin{abstract}
Acacia auriculiformis Cunn. Ex. Benth is a multipurpose wattle tree with diverse environmental and ecological significance. However, seeds dormancy and low germination percentage are problems for its use in agro-forestry practices. Investigations were carried out on the effect of pre - treatment on the germination and early seedlings growth of $A$. auriculiformis. Germination were observed in seeds pretreated with sulphuric acid at 7days after sowing (DAS) while seeds under the nitric acid and control treatment germinated at 8 and 9 DAS respectively. Results, shown that pre - sowing treatments have positive influence on seed germination; seeds treated with Conc. $\mathrm{H}_{2} \mathrm{SO}_{4}$ for 5 to 10 min had the highest percentage germination of $92-96 \%$ compared with $42 \%$ for the control treatment. The effect of different pre-treatment test, their interaction and time of exposure significantly $(P<0.05)$ influenced seedlings growth parameters. The highest mean shoot length and stem diameter values of $5.92 \mathrm{~cm}$ and $0.29 \mathrm{~mm}$ respectively were recorded among seedlings that originated from seeds pre - treated with sulphuric acid for 5 and $10 \mathrm{~min}$. Hence, dormancy in A. auriculiformis seeds can be removed by pre - treatment with sulphuric acid ( 5 and10 $\mathrm{min}$ ) with enhanced percentage germination and growth performances.
\end{abstract}

Key words: A. auriculiformis, seeds, pre-treatment, germination, growth.

\section{INTRODUCTION}

New initiatives in agro forestry are seeking to promote poverty alleviation and environmental rehabilitation in developing countries through the integration of indigenous trees whose products have been gathered from natural forests into tropical farming system (Hossner and Juo, 1999). Leakey and Simons (2004) showed that one important component of this approach is the domestication of the local tree species that have commercial potentials in local, regional or even international markets.

With rapid population growth, these forest resources are being depleted owing to the increasing demand for forest products (Kayode, 2006). Chandel and Shulka (2002) also reported that the unprecedented demand for

*Corresponding author. E-mail: dammy4real13@yahoo.com. Tel: +2348038147077 . productive land for agriculture use has reduced plant species availability. Deforestation reduces species diversity and erodes the genetic base of the tropical trees, including those vital for the survival of the present generation. In addition, Leakey (1998) suggested that deforestation may leads to disruption of the closed nutrient recycle and severe degradation of natural resources base of the environment.

Leakey (1998) noted that agro-forestry is a more sustainable form of land use that holds a greater potential of improving farm productivity through enhanced soil fertility. In recent years, there had been a growing interest in optimizing the value and role of high value indigenous species in tree based cropping system of West and Central Africa (Tchoundjeu et al., 1999). The development of alley cropping system came as a response to the need to manage soils with poor fertility, thus food crops are grown in the alleys formed by hedgerows of planted trees and shrubs preferably legumes. Acacia auriculiformis 
with its agro forestry potentials fits into this role.

A. auriculiformis A. Cunn ex. Benth (family - Fabaceae) is a leguminous and multipurpose tree which is found in many tropical zones of Southeast Asia, Africa and Latin America (Das and Alam, 2001; Simons and Leakey, 2004). This plant species grows very fast, with the ability to fix nitrogen, thrive on infertile, acid, alkaline, saline and waterlogged soils (Hossain et al., 1997). Successful use of $A$. auriculiformis in agro-forestry programme in Africa and Bangladesh has been reported owing to its rapid growth, short rotation and ability to thrive on degradable soil (Amin et al., 1995). A. auriculiformis is a potential plant for erosion control, water conservation and also a source of biomass for fuel generation (Hossain et al., 2009). Domestication of this species and its subsequent integration into the agro ecosystem requires the mass production of its seedlings. Seed dormancy with its attendant poor, slow and difficult germination hampers agro-forestry and afforestation efforts (Zabala, 1991).

This challenge of seed coat imposed dormancy has also being demonstrated by other members of the Acacia generic name; Acacia tortilis (Forsk), Acacia Seyal (Del) and Acacia nilotica (L) (Msanga, 1998; Albrecht, 1993). However, the principal methods used for breaking of seed dormancy in Acacia species has been the use of hot water and mechanical scarification (nicking) (Cervantes et al., 1996; Tadros et al., 2011). Acid scarification is another method of physical scarification which has been found valuable in the breaking of seed dormancy during plantation establishment (Azadet et al., 2006a; Gonçalves et al., 2011; Pipinis et al., 2011). In other words, the use of acid scarification and exposure time in breaking seed dormancy in A. auriculiformis is poorly documented. Hence, this study is conducted to determine the best presowing treatment and time of exposure that can enhance the percentage germination and seedling growth at nursery stages under agro-forestry programme.

\section{MATERIALS AND METHODS}

\section{Plant materials}

Mature seeds of the multipurpose tropical wattle $A$. auriculformis were collected from Forestry Research Institute of Nigeria (FRIN), Umudike (Lat. $5^{\circ} 30^{\prime} \mathrm{N}$ and Long. $5^{\circ} 32^{\prime} \mathrm{E}$ ) Abia State, Nigeria and transported to the department of Plant Science Biotechnology's Laboratory, Adekunle Ajasin University, Akungba (Lat. $7^{\circ} 28^{\prime} \mathrm{N}$ and Long. $5^{\circ} 27^{\prime}$ E) Ondo State, Nigeria.

\section{Seed treatments}

There were 11 treatments; Control (To), hot water for $12 \mathrm{~h}\left(\mathrm{~T}_{1}\right)$, Conc. sulphuric acid $\left(\mathrm{H}_{2} \mathrm{SO}_{4}\right)$ for $2 \mathrm{~min}\left(\mathrm{~T}_{2}\right)$, Conc. $\mathrm{H}_{2} \mathrm{SO}_{4}$ for $5 \mathrm{~min}$ $\left(\mathrm{T}_{3}\right)$, Conc. $\mathrm{H}_{2} \mathrm{SO}_{4}$ for $10 \mathrm{~min}\left(\mathrm{~T}_{4}\right)$, Conc. nitric acid $\left(\mathrm{HNO}_{3}\right)$ for $2 \mathrm{~min}$ $\left(T_{5}\right)$, Conc. $\mathrm{HNO}_{3}$ for $5 \mathrm{~min}\left(\mathrm{~T}_{6}\right)$, Conc. $\mathrm{HNO}_{3}$ for $10 \mathrm{~min}\left(\mathrm{~T}_{7}\right)$, Conc. sodium hypochlorite $(\mathrm{NaClO})$ for 2 min $\left(\mathrm{T}_{8}\right)$, Conc. $\mathrm{NaClO}$ for $5 \mathrm{~min}$ $\left(\mathrm{T}_{9}\right)$. and Conc. $\mathrm{NaClO}$ for $10 \mathrm{~min}\left(\mathrm{~T}_{10}\right)$. Each treatment has one hundred in five seed replicates $(5 \times 20)$, making a total of 1,100 $(11 \times 5 \times 20)$ seeds that were used for the whole treatment combina- tions. The seeds under chemical scarification and hot water treatments were gently stirred periodically and after the pre treatment durations, seeds were washed thoroughly under running tap water to remove acid residual and other chemicals. The pre- treated seeds were air- dried for $24 \mathrm{~h}$ before sowing. Sterilized river sand was used as the sowing media for the pre-treated seeds. One seed per treatment was sown at a depth of $0.51 \mathrm{~cm}$ in a small well labelled germination trays and they were watered manually once a day.

\section{Germination percentages estimation}

Germination study was observed for 6 weeks and the number of seeds germinated in each treatment was recorded in every alternate day. Germination was observed in the seeds when the first leaf emerges as well as the radicle. At the end of the germination period, the germination percentage and germination rate (Maguire, 1962) was calculated using the following equations:

Germination percentage $=\frac{\text { Number of seeds germinated }}{\text { Number of seeds on tray }} \times 100$

\section{Growth parameters}

After the completion of the germination experiment, a total of 35 single plant replicates from each of the 11 pre- treatment test were transplanted into poly pots containing top soil. Growth parameters such shoot length, collar diameter and number of leaves were assessed fortnightly after two weeks of transplanting for 4 four months. Total shoot length was measured by using ruler (taken from the apical bud of the plant to the base of the shoot) and stem diameter by using electronic digital caliper $(6 " / 150 \mathrm{~mm}$, accuracy \pm $0.02 \mathrm{~mm}$, LR44, 2006/66/EC)

\section{Statistical analysis}

The data obtained for seed germination percentage were statistically analysed using the analysis of variance (ANOVA) procedure of SAS 9.2 software package and the means of the shoot length, collar diameter and number of leaves were tested using Duncan Multiple Range Test (DMRT).

\section{RESULTS}

\section{Seed germination}

Germination were observed in seeds pre - treated with sulphuric acid (2-10 min) and $\mathrm{NaClO}$ for 10 min at 7 days after sowing (DAS) while seeds under the nitric acid treatment $(2-10 \mathrm{~min})$ and $\mathrm{NaClO}$ for 5 min sprouted at 8 DAS. Seeds treated with $\mathrm{NaClO}$ for 2 min were the last batch to germinate at 10 DAS. Percentage germination were highest among seeds treated with sulphuric acid with values of 96,92 and $79 \%$ obtained for seeds under 10, 5 and 2 min respectively. However, the percentage germination of seeds treated with; nitric acid, sodium hypochlorite (2, 5 and $10 \mathrm{~min})$, hot $\mathrm{H}_{2} \mathrm{O}$ for $12 \mathrm{~h}$ and the Control were below 56 (Figures 1 and 2). 


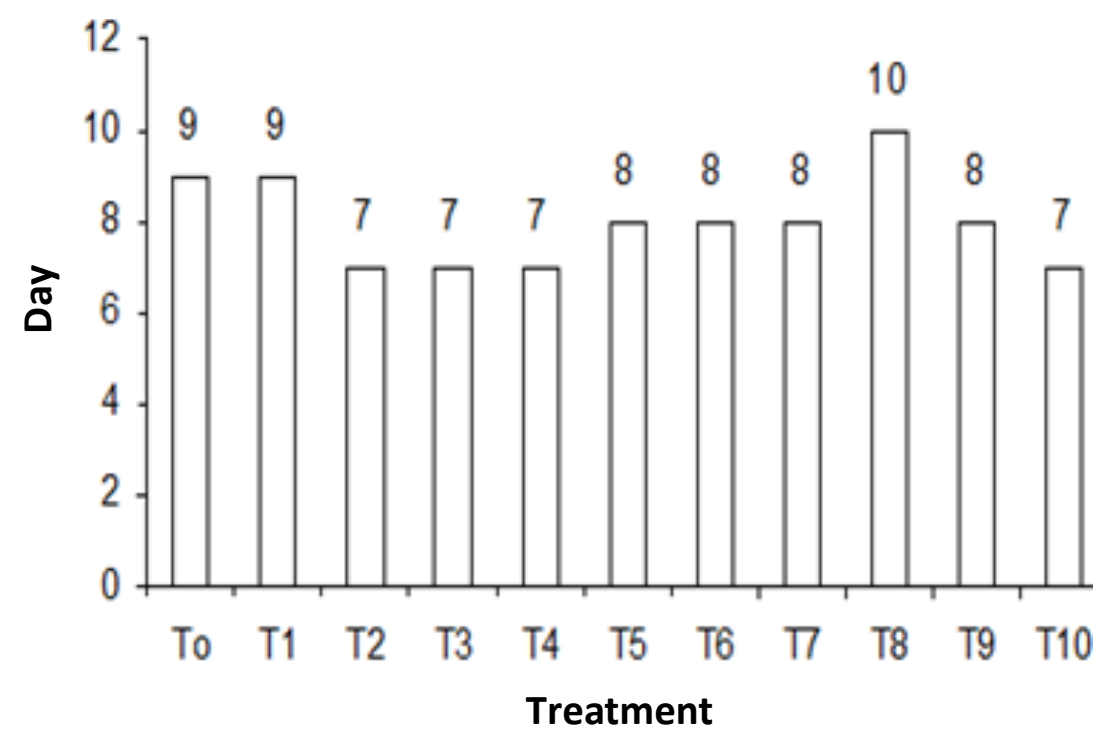

Figure 1. Showing the effect of different pre - treatment test on the germination of A. auriculformis over a period of twelve (12) days after sowing (DAS). Control (To), hot water for $12 \mathrm{~h}\left(\mathrm{~T}_{1}\right)$, conc. sulphuric acid $\left(\mathrm{H}_{2} \mathrm{SO}_{4}\right)$ for $2 \mathrm{~min}\left(\mathrm{~T}_{2}\right)$, conc. $\mathrm{H}_{2} \mathrm{SO}_{4}$ for 5 min $\left(\mathrm{T}_{3}\right)$, conc. $\mathrm{H}_{2} \mathrm{SO}_{4}$ for $10 \mathrm{~min}\left(\mathrm{~T}_{4}\right)$, conc. nitric acid $\left(\mathrm{HNO}_{3}\right)$ for 2 min $\left(\mathrm{T}_{5}\right)$, conc $\mathrm{HNO}_{3}$ for $5 \mathrm{~min}\left(\mathrm{~T}_{6}\right)$, conc. $\mathrm{HNO}_{3}$ for $10 \mathrm{~min}\left(\mathrm{~T}_{7}\right)$, conc. sodium hypochlorite $(\mathrm{NaClO})$ for $2 \mathrm{~min}\left(\mathrm{~T}_{8}\right)$, conc. $\mathrm{NaClO}$ for $5 \mathrm{~min}\left(\mathrm{~T}_{9}\right)$ and conc. $\mathrm{NaClO}$ for $10 \mathrm{~min}$ $\left(\mathrm{T}_{10}\right)$.

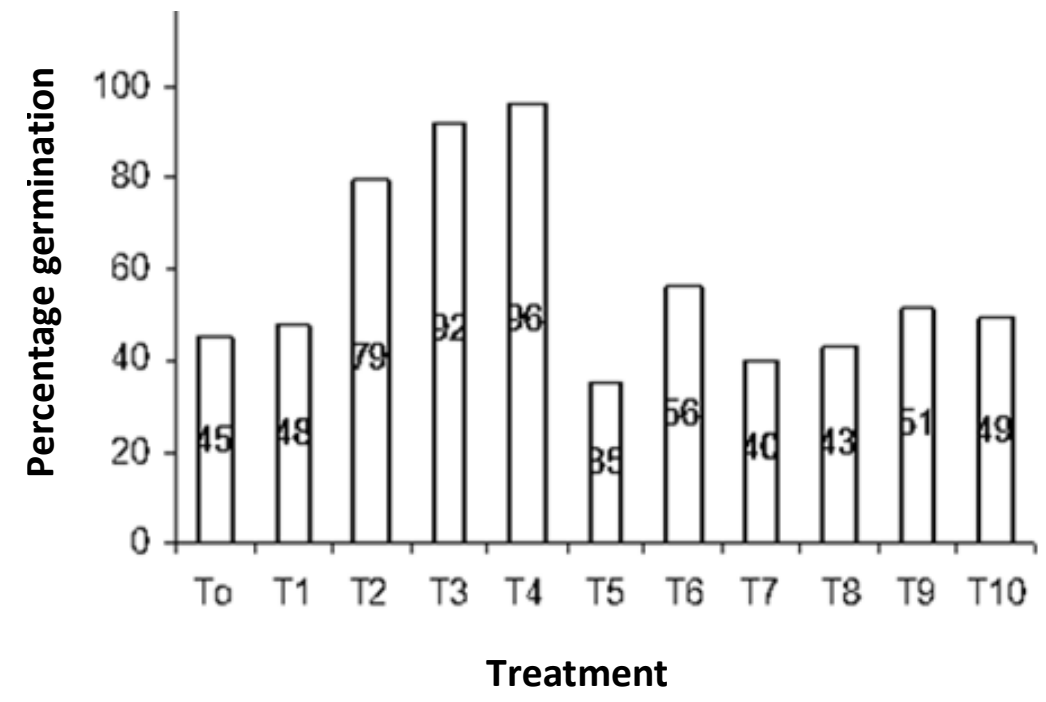

Figure 2. Depicting the effect of pre - sowing treatments on the percentage germination of $A$. auriculformis over a period of six (6) weeks. Control (To), hot water for $12 \mathrm{hr}\left(\mathrm{T}_{1}\right)$, conc. sulphuric acid $\left(\mathrm{H}_{2} \mathrm{SO}_{4}\right)$ for 2 min $\left(\mathrm{T}_{2}\right)$, conc. $\mathrm{H}_{2} \mathrm{SO}_{4}$ for 5 min. $\left(\mathrm{T}_{3}\right)$, conc. $\mathrm{H}_{2} \mathrm{SO}_{4}$ for $10 \mathrm{~min}\left(\mathrm{~T}_{4}\right)$, conc. nitric acid $\left(\mathrm{HNO}_{3}\right)$ for 2 min $\left(T_{5}\right)$, conc. $\mathrm{HNO}_{3}$ for $5 \mathrm{~min}\left(\mathrm{~T}_{6}\right)$, conc. $\mathrm{HNO}_{3}$ for $10 \mathrm{~min}\left(\mathrm{~T}_{7}\right)$, conc. sodium hypochlorite $(\mathrm{NaClO})$ for $2 \mathrm{~min}\left(\mathrm{~T}_{8}\right)$, conc. $\mathrm{NaClO}$ for $5 \mathrm{~min}\left(\mathrm{~T}_{9}\right)$ and conc. $\mathrm{NaClO}$ for $10 \mathrm{~min}\left(\mathrm{~T}_{10}\right)$.

\section{Seedlings growth performance}

\section{Shoot length}

The effect of different pre - treatment test and exposure period significantly $(p<0.05)$ influenced the mean shoot length values of $A$. auriculformis (Table 1). The highest mean length value of $5.92 \mathrm{~cm}$ was recorded among seedlings that was produced from seeds treated with sulphuric acid for $5 \mathrm{~min}$, followed by seedlings that originated from 
Table 1. Showing summary of analysis of variance of the effects of different pre - treatment test on shoot length and stem diameter growth and number of leaves of $A$. auriculiformis at nursery stages.

\begin{tabular}{|c|c|c|c|c|c|c|c|c|c|c|}
\hline \multicolumn{5}{|c|}{ Height } & \multicolumn{3}{|c|}{ Collar diameter } & \multicolumn{3}{|c|}{ Number of leave } \\
\hline SV & DF & SS & MS & F.V & SS & MS & F.V & SS & MS & F.V \\
\hline Treatment & 10 & 143.40 & 14.34 & $13.87^{*}$ & 0.35 & 0.03 & $14.20^{*}$ & 130.82 & 13.08 & $3.72^{*}$ \\
\hline Error & 979 & 1012.43 & 1.03 & & 2.46 & 0.00 & & 3439.72 & 3.51 & \\
\hline Total & 989 & 1155.83 & & & 2.83 & & & 3570.5 & & \\
\hline
\end{tabular}

Values with * are significantly different at $p<0.05$. SV, source of variation; DF, degree of freedom; SS, sum of squares; MS, mean square; FV, F value.

Table 2. Summary of different pre-sowing treatment effects on shoot length, stem diameter growth and number of leaves of $A$. auriculiformis.

\begin{tabular}{cccc}
\hline Treatment & Height $(\mathbf{c m})$ & Stem diameter $(\mathbf{m m})$ & Number of leaves \\
\hline $\mathrm{T}_{\mathrm{O}}$ & $5.52^{\mathrm{bc}}$ & $0.27^{\mathrm{bc}}$ & $3.69^{\mathrm{d}}$ \\
$\mathrm{T}_{1}$ & $5.08^{\mathrm{de}}$ & $0.25^{\mathrm{d}}$ & $3.97^{\mathrm{bcd}}$ \\
$\mathrm{T}_{2}$ & $5.52^{\mathrm{bc}}$ & $0.27^{\mathrm{bc}}$ & $3.77^{\mathrm{cd}}$ \\
$\mathrm{T}_{3}$ & $5.92^{\mathrm{a}}$ & $0.29^{\mathrm{a}}$ & $4.23^{\mathrm{bcd}}$ \\
$\mathrm{T}_{4}$ & $5.78^{\mathrm{ab}}$ & $0.28^{\mathrm{ab}}$ & $3.97^{\mathrm{bcd}}$ \\
$\mathrm{T}_{5}$ & $5.44^{\mathrm{c}}$ & $0.27^{\mathrm{bc}}$ & $3.88^{\mathrm{cd}}$ \\
$\mathrm{T}_{6}$ & $4.88^{\mathrm{ef}}$ & $0.25^{\mathrm{d}}$ & $4.54^{\mathrm{ab}}$ \\
$\mathrm{T}_{7}$ & $4.61^{\dagger}$ & $0.23^{\mathrm{e}}$ & $4.95^{\mathrm{a}}$ \\
$\mathrm{T}_{8}$ & $5.06^{\mathrm{e}}$ & $0.25^{\mathrm{d}}$ & $4.54^{\mathrm{ab}}$ \\
$\mathrm{T}_{9}$ & $5.38^{\mathrm{cd}}$ & $0.26^{\mathrm{c}}$ & $4.37^{\mathrm{bbc}}$ \\
$\mathrm{T}_{10}$ & $4.88^{\mathrm{e}}$ & $0.25^{\mathrm{d}}$ & $4.24^{\mathrm{bcd}}$ \\
\hline
\end{tabular}

Means in a column with similar letters are not significantly different at $5 \%$ level of probability according to Duncan Multiple Range Test.

seeds under $\mathrm{H}_{2} \mathrm{SO}_{4}$ for 10 min $(5.78 \mathrm{~cm})$, while the lowest mean height value of $4.61 \mathrm{~cm}$ were obtained from seedlings that evolved from seeds pre - treatment with sodium hypochlorite for $2 \mathrm{~min}$. The average shoot length values of seedlings that had their seeds soaked in $\mathrm{H}_{2} \mathrm{SO}_{4}$ for 5 and 10 min were not significantly different from each other but differ significantly from other treatments (Table 2).

\section{Stem diameter}

Seedling stem diameter was significantly $(p<0.05)$ influenced by different pre - sowing treatments and exposure time (Table 1). Seedlings originated from seeds soaked with sulphuric acid (5 $\mathrm{min}$ ) had the highest mean stem diameter value of $0.29 \mathrm{~mm}$, followed by $0.28 \mathrm{~mm}$ $\left(\mathrm{H}_{2} \mathrm{SO}_{4}\right.$ for $\left.10 \mathrm{~min}\right)$, while the lowest mean stem diameter value of $0.23 \mathrm{~mm}$ was obtained among seedlings under nitric acid treatment (10 min). The mean stem diameter values of seedlings obtained from seeds pre - treated with sulphuric acid (5 and $10 \mathrm{~min}$ ) were not significantly different from each other. However, they were significantly different from other treatments (Table 2).

\section{Number of leaves}

Pre - treatment and exposure time significantly $(p<0.05)$ influenced the mean number of leaves values of $A$. auriculformis (Table 1). Mean number of leaves were highest (4. 95) in seedlings that originated from seeds under nitric acid (10 $\mathrm{min}$ ), followed by seedlings raised from seeds soaked in sodium hypochlorite pre - treatment test for 2 min (4.54) while the least mean number of leaves value (3.69) was obtained in seedlings under the control treatment. Hence, the mean number of seedling that had their seeds pre - treated with nitric acid for $4 \mathrm{~min}$ was significantly different from other pre - sowing treatments (Table 2).

\section{DISCUSSION}

Different approaches of breaking seed dormancy, in order 
to enhance germination rate and to increase germination process were argued by many authors (Yadav, 1992; Alamgir and Hossain, 2005a, b; Airi et al., 2009; Azad et al., 2010a; b). Among the methods used in breaking seed dormancy include physical scarification of seed coat by nicking; filling with needles, knife and or abrasion paper (Schmidt, 2000). In addition, methods such as acid treatment (Kobmoo and Hellum, 1984; Pipinis et al., 2011) or hot water treatment (Schmidt, 2000) can be used to overcome physical seed dormancy. Hossain et al. (2005) reported that seeds with hard, solid, impermeable seed coat were noted to establish germination after pre- sowing treatments However, breaking of seed dormancy varies from species to species. Therefore, it is very important to determine which method and condition is suitable for each plant species.

In this study, $A$. auriculiformis seeds treated with concentrated sulphuric acid treatment produced the highest percentage germination among the acid pre treatment test. Seeds that were soaked in $\mathrm{H}_{2} \mathrm{SO}_{4}$ for 10 min recorded the best germination percentage of $96 \%$, followed by those seeds treated with $\mathrm{H}_{2} \mathrm{SO}_{4}$ for $5 \mathrm{~min}$ $(92 \%)$ and the least among the sulphuric treatment was $76 \%$ (2 min) even as seeds under the control treatment had $42 \%$. The considerable germination percentage with concentrated sulphuric acid scarification occurred as a result of the ability of the acid to degrade the seed coat of $A$. auriculiformis thereby re-activating the physiological and biochemical activities needed for seed germination. This result was in agreement with the report of Mohammad and Amusa (2003) on the superiority of sulphuric treatment compared with other tested treatments on germination of tamarind seeds. Similarly, Pipinis et al. (2011) noted that sulphuric acid treatment proved more effective than nitric acid and alcohol in breaking dormancy. The increased exposure regime of $A$. auriculiformis seeds to sulphuric acid treatment considerably increased the germination rate from $42 \%$ (control) to $96 \%\left(\mathrm{H}_{2} \mathrm{SO}_{4}\right.$ for $10 \mathrm{~min}$ ). This enhanced seed germination with increasing treatment time was also reported by Awodola (1994), Aduradola and Shinkafi (2003) for Parkia biglobosa (Jacq) Don. and Tamarindus Indica Linn. In addition, this is also similar to the report by Duguma et al. (1988) that germination percentage increased with longer treatment time of acid treatment in Leucaena leucoephala seeds apart from the better germination of $A$. auriculiformis seeds with acid scarification, other plant species such as Calligonum benghalensis aerial seeds (Kim et al., 1990) and Pushina trachea had experienced significant germination with sulphuric acid treatment (Meyer and Poljakoff-Mayer, 1982). Consequently, Ren and Tao (2004) reported that conc. sulphuric acid treatment recorded superior germination rate in Calligonum species compared to cold scarification treatment. The effect of $\mathrm{H}_{2} \mathrm{SO}_{4}$ on promotion of seed germination might be due to the highly desiccant effect of the acid on the seed coat there by allowing easier water uptake and oxygen diffusion.

From the results, it is evident that seedlings raised from seeds soaked in sulphuric acid with increasing exposure regime from 2 to $10 \mathrm{~min}$ had the best vegetative characters (shoot length, stem diameter) which concurred with the result of El-Juhany et al. (2009) on the seedlings of Juniperus procera. Success of seedlings production depends on germination capacity from damping off, survivorship and increase in size. Therefore, dormancy in $A$. auriculiformis seeds can be removed by pre - treatment with sulphuric acid (5 and10 $\mathrm{min}$ ) with enhanced percentage germination and growth performances.

\section{REFERENCES}

Aduradola AM, Shinkafi MA (2003).Aspects of seed treatment for germination in Termarindus indica Linn. ASSET Series A. 33(4):2934.

Airi S, Bhatt ID, Bhatt A, Rawal RS, Dhar U (2009). Variations in seed germination of Hippophae salicifolia with different presoaking treatments. J. Forest. Res. 20(1): 27 -30.

Alamgir M, Hossain M (2005a). Effect of pre-sowing treatments on Albizia procera (Roxb.) Benth seeds and initials development of seedlings in the nursery. J. Forest. Environ. 3:53-60.

Alamgir M, Hossain MK (2005b). Effect of pre-sowing treatments on germination and initials seedling development of Albizia saman in the nursery. J. Forest. Res. 16(3):200-204.

Amin SMR, Ali MO, Fattah MIM (1995). Eucalypts in Bangladesh. In: Proceedings of a seminar held at Bangladesh Agricultural Research Council on April 06, 1994.

Awodola AM (1994). Aspects of germination in seeds of African locust bean tree Parkia biglobosa (Jacq) Don. J. Trop. Forest Res. 10:8291.

Azad MS, Musa ZA, Matin A (2010a). Effect of pre-sowing treatments on seed germination of Melia azedarach. J. Forest. Res. 21(2):193196.

Azad MS, Paul NK, Matin MA (2010b). Do pre-sowing treatments affect seed germination in Albizia richardiana and Lagerstroemia speciosa? Frontiers Agric. China 4(2):181-184.

Chandel PS, Shulka RS (2002). A Textbook of Plant Ecology Including Ethnobotany and Soil Science. p. 549.

Das DK, Alam MK (2001). Trees of Bangladesh. Chittagong, Bangladesh: The Art Press. p. 11.

Duguma B, Kaiw BT, Okali DUU (1988). Factors affecting germination of Leucaenia leucocephala. Seed Sci. Technol. 16:489-500.

El-Juhany LL, Aref IM, Al - Ghamdi MA (2009). Effects of Different Pretreatments on Seed Germination and Early Establishment of the seedlings of Juniperus procera Trees. World Appl. Sci. J. 7(5):616624.

Gonçalves EP, Soares FSJ, Silva SD, Tavares DS, Viana JS, Cardoso BCC (2011). Dormancy Breaking in Ormosia arborea Seeds. Int. J. Agron. p. 5.

Hossain MA, Arefin MK, Khan BM, Rahman MA (2005). Effects of Seed Treatments on Germination and Seedling Growth Attributes of Horitaki (Terminalia chebula Retz.) in the nursery. Res. J. Agric. Biol. Sci. 1(2):135-141

Hossain MK, Islam SA, Zashimuddin M, Tarafdar, MA, Islam QN (1997). Growth and biomass production of some Acacia and Eucalyptus species in degraded Sal forest areas in Bangladesh. Indian Forester. 23(3):211-217.

Hossain L, Huda SMS, Hossain MK (2009). Effects of industrial and residential sludge on seed germination and growth parameters of Acacia auriculiformis seedlings. J. For. Res. 20(4):331-336.

Hossner LR, Juo ASR (1999). Soil Nutrient Management for sustained Food Crop Production in Upland Farming Systems in the Tropics. p. 18. http://www.agnet.org/htmlarea_file/library. 
Kayode J ( 2006). Conservation in Nigeria Perspective. p. 50 .

Kim SY, DeDatta SK, Mercado BL (1990). The effect of chemical and heat treatments on germination of Cormmenlina benghalensis $\mathrm{L}$. aerial seeds. Weeds Res. 30:109-116.

Kobmoo B, Hellum AK (1984). Hot water and acid improve the germination of Cassia siamea Britt. Seeds. Embryan 1(1):27-33.

Leakey RRB (1998). Agroforestry in the Humid Lowland of West Africa. Some Future Directive in Res. In Duguma. B (ed). Agroforestry (Special issue) 1(4):33-60.

Maguire JD (1962). Speed of germination in selection and evaluation for seedling vigour. Crop Sci. 2:176-177.

Meyer AM, Poljakoff-Mayer A (1982). The germination of seeds, Penganen Press Ltd, England, p. 200.

Pipinis E, Milios E, Smiris P, Gioumousidis C (2011). Effect of acid scarification and cold moist stratification on the germination of Cercis siliquastrum L. seeds Turk J. Agric. For. 35:259-264.

Ren J, Tao L (2004). Effect of different pre-sowing seed treatments on germination of 10 Calligonium species. For. Ecol. Manag. 195:291300.
Schmidt L (2000). Guide to handling of tropical and subtropical forest seeds. Danida Forest. Seed Centre. Humlebaeck, Denmark.

Simons AJ, Leakey RRB (2004). Tree domestication in tropical agroforestry. Agrofor. Syst. 61:167-181.

Tadros MJ, Samarah NH, Alqudah AM (2011). Effect of different presowing seed treatments on the germination of Leucaena leucocephala (Lam.) and Acacia farnesiana (L.) New For. 42:397407.

Tchoundjeu Z, Duguma B, Tientcheu ML, Ngo Mpeck ML (1999). Domestication of indigenous agroforestry tree: ICRAF's Strategy in the humid tropics of west and Central Africa.

Yadav JP (1992). Pretreatment of teak seed to enhance germination. Indian Forester, 11(2):260-264.

Zabala NQ (1991). Plantation Silviculture. Development of professional Education in the forestry sectors. Institute of Forest. Chittagong Univ. FAO. Chittagong, Bangladesh. 